\title{
A Potential Tsunami impact assessment of submarine landslide at Baiyun Depression in Northern South China Sea
}

\author{
Sun Yongfu ${ }^{1}$ and Huang Bolin ${ }^{2^{*}}$
}

\begin{abstract}
Background: With mature hydrocarbon industry, Northern South China Sea (NSCS) is a hot spot for future economic development. However, the local government and researchers lack of estimations about damages brought by a submarine landslide-generated tsunami. According to oceanographic surveys, eleven landslides in different scale have been discovered in Baiyun Depression of NSCS. Hence, the need to study potential tsunamis generated by submarine landslides in NSCS is urgent and necessary. This research, focused on potential threat linked to local tsunami sources, is in its early stage in China but it is of capital importance for the local people, local government and offshore economics.
\end{abstract}

Finding: Taking landslide $\mathbf{S 4}$ for example, the formation, spreading and run-up are predicted. As calculated, the greatest height of tsunami generated by Landslide S4 is $17.5 \mathrm{~m}$, occurring near Dongsha Islands, and the greatest run-up formed on the coastal line is $5.3 \mathrm{~m}$, occurring near Shanwei City; the general height of waves attacking the coastal line is no more than $1.5 \mathrm{~m}$, but abnormally high waves might occur in 32 regions.

Conclusions: Prediction of tsunami generated by Landslide S4 suggests that local landslides in NSCS may trigger tsunami hazards. Therefore, more efforts shall be made to investigate potential damages caused by a submarine landslide, particularly the submarine landslides at Baiyun Depression in NSCS.

Keywords: Northern South China Sea; Baiyun Depression; Submarine landslide; Tsunami hazard assessment

\section{Introduction}

Submarine landslides are major natural marine disasters endangering deepwater oil and gas exploration and development platforms, pipelines, submarine cables and other submarine facilities (NGI 2005). Meanwhile, submarine landslides can generate local tsunamis with high run-ups, posing a hazard to human lives and coastal facilities in huge range (Levin and Nosov 2009). Tinti et al. (1999) used numerical analogy to analyze the tsunami generated by the landslide of Vulcano Island in 1988. Tinti and Bortolucci (2000) used 1D and 2D shallow-water wave models to analyze energy transmission from a submarine landslide to a water body. Rahiman et al. (2007) established submarine landslide-generated surge source model and earthquakegenerated tsunami model for numerical simulation of

\footnotetext{
* Correspondence: bolinhuang@aliyun.com

${ }^{2}$ Wuhan Center of China Geological Survey, Guanggu Road 69\#, Wuhan City, China

Full list of author information is available at the end of the article
}

Suva Tsunami in 1953. Fuchs et al. (2010) used numerical simulations and physical tests to compare and analyze attacks by a tsunami to an island. Sascha et al. (2010) assessed dangers posed by tsunamis generated by underwater landslides near Padang Island of Indonesia. According to ITDB/WLD (2007) data, tsunamis caused by landslides accounted for at least $8 \%$ of the historical tsunami events. Therefore, with the development of offshore industry, it is necessary to investigate submarine landslides for potential tsunamis hazard assessment.

Few reports and studies about local submarine landslidegenerated tsunamis have been done in China, though local submarine landslide-generated tsunamis may possibly occur. In November 1991, a submarine landslide occurred during the preliminary pile sinking process of the 200,000 ton-scale crude oil terminal project of China Sinopec at Aoshan, Xingzhong, having caused collapse of many pile foundations and generated a 2-3 m tsunami (Hu and Ye 2006). Chen et al. (2007) analyzed tsunami 
hazards in China based on physical occurrence conditions of tsunamis, he believed that major tsunamis in south-east coastal areas of China is possibly in the south, for example, violent earthquakes west to the Philippines, volcanoes at Sunda Straits of Indonesia and large submarine landslides in tsunamis in South China Sea. Geological survey from 1990s showed that there were many large landslides in NSCS (Marine Geological Survey Bureau of the Ministry of Geology and Mineral Resources, China 1993). Fen et al. (1994) discovered a wide range of submarine landslide at the outer continental shelf and upper continental slope of NSCS, at the depth of about 180-650 m. Yang et al. (2011) described, in details, the types and features of geological disasters in the deepwater area to south-east Hainan in South China Sea. Sun et al. (2008) described the geometrical shapes and deforming characteristics of Baiyun Landslide, a large submarine landslide discovered in NSCS, by using the multi-beam water depth strategy and 3D seismic data. Sun (2011) had deep research on the forming mechanism of geological disasters in the deepwater continental slope area of NSCS; one of important inclusion is that the submarine landslide in NSCS is relative to hydrocarbon. Liu (2010) analyzed, by taking the northern area of as an example, the impact of high pore pressure and water precipitation resulted from natural gas hydrate decomposition on submarine landslides.

It can be seen from the foregoing studies that there are landslides in the NSCS which are unstable submarine areas of South China Sea and origins of potential local tsunamis. Meanwhile, Baiyun Depression is located at Zhujiangkou Basin, an area with relatively mature development of hydrocarbon in China (Jiang 2009); a submarine landslide occurs in this area may cause profound impact and damages. Based on data from many marine geological surveys (Marine Geological Survey Bureau of the Ministry of Geology and Mineral Resources, China 1993; Sun et al. 2008), this paper studies the characteristics of submarine landslides in NSCS, did numerical calculations of possible tsunamis to be generated by the landslides, and analyzed the tsunami hazards that may be caused by submarine landslide.

\section{Geological setting}

Many submarine landslides in NSCS are located at transitional belts between continental shelves and deepwater continental slopes, with the water depth of about 200-2000 m, most of which are at the water depth of 500-1500 m. The shallow-water area is the north continental shelf of South China Sea at Zhujiangkou Basin (Figure 1). Due to structural difference during formation of the continental shelf, up-and-down movements and sediment sources, water depth at the outer bend of the continental shelf ranges between 145-379 $\mathrm{m}$. Beyond the slope bend, there is a sharp continent slope with a gradient of more than ten times that of the continental shelf. In tectonic side, the deepwater area can be also classified into Zhujiangkou Basin, and most at Baiyun Depression Region. The depression in this area covers over $20,000 \mathrm{~km}^{2}$; it is the greatest depression with the thickest sediment in Zhujiangkou Basin.

Through the analysis of data from deepwater area drilling, tracing and interpretation of many seismic reflection profiles at Zhujiangkou Basin where Baiyun Depression is located (Liu 2010), and comparison of adjacent strata it was observedthat eight sets of seismic sequences have been developed in the deepwater area of Zhujiangkou Basin, i.e. the Quaternary System, Wanshan Formation,

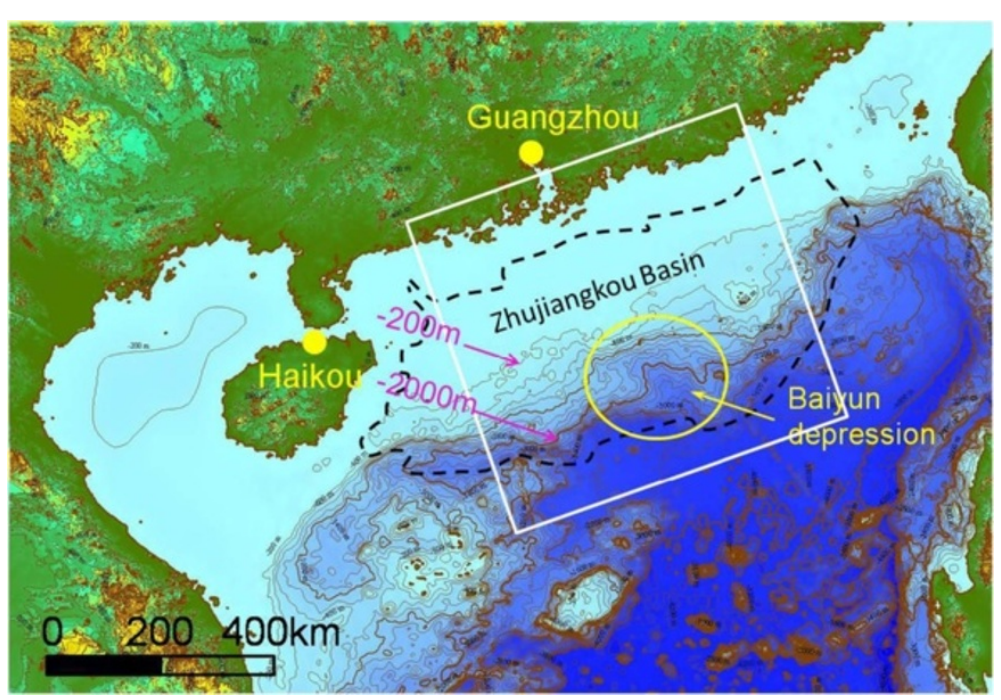

Figure 1 Geological background skecth map of NSCS, the black dashed frame is the location of Zhujiangkou Basin, the white box is our study area and the location of Figure 2 (Data from SRTM). 
Yuehai Formation, Hanjiang Formation, Zhujiang Formation, Enping Formation and Wenchang Formation strata from up to down (Sun et al. 2008). In Wenchang Formation and Enping Formation, lacustrine deposit and large lake basin deposit are developed, respectively, mainly comprising source rocks. In Zhuhai Formation, large neritic shelf deposit is developed. In Zhujiang Formation and Hanjiang Formation, continental slope deepwater deposit is developed (Sun 2011).

Baiyun Depression experienced three evolving formation stages, which are rift stage, thermal subsidence stage and neotectonic stage in the Cenozoic (Gong and Li 1997; Zhu et al. 2007), and formed "three uplifts and two depressions", featuring great terrain fluctuations and sharp gradients. Baiyun Depression was preliminarily formed at the rift stage. At the thermal subsidence stage, major block of Baiyun Depression sank fast and greatly; the ancient Zhujiang Delta moved to deposit in the depression, providing plenty of sediment sources (MiL and Shen 2008). At the neotectonic stage, structural sedimentation velocity and scale, as well as depositing rate and scale are in succeeded development; and many late faults were developed at Baiyun Depression and its surrounding area due to NWW subduction of Philippine plate, having created structural conditions for development of submarine landslides (Sun et al. 2005). Through study on pressure evolution of Baiyun Depression strata, it is found that the stratum pressure of Baiyun Depression is normal at the shallow-water area, and weak in the deepwater area; however, wide range of diapir structure in the Depression suggests that the area might have experienced three times of overpressure accumulations and release in the late period (Shi et al. 2006), creating pressure condition for development of submarine landslides.

ZhujiangRiver provides Zhujiangkou Basin with plenty of sediment sources, with depositing rate up to $160 \mathrm{~cm} / \mathrm{ka}$, creating geological condition for gravity-triggered landslides (Sun 2011). Moreover, this region is intensive submarine geological exploration area, both drilling and the decomposition of hydrocarbon may induce landslides (Locat and Lee 2002; Fang and Zhang 2010).

\section{Submarine landslide descriptions}

Due to geological structure, landform and complex submarine dynamic conditions, Baiyun Depression in NSCS has well developed landslide mass, sliding sand slope, large erosion gullies, submarine scarps and other unstable landforms; it is an area with rather unstable submarine engineering geological conditions in NSCS. According to oceanic geotechnical surveys (Marine Geological Survey Bureau of the Ministry of Geology and Mineral Resources, China 1993; Sun et al. 2008), Baiyun Depression has eleven submarine landslides with different scales, whose codes are S1 S11 (Figure 2). Except for

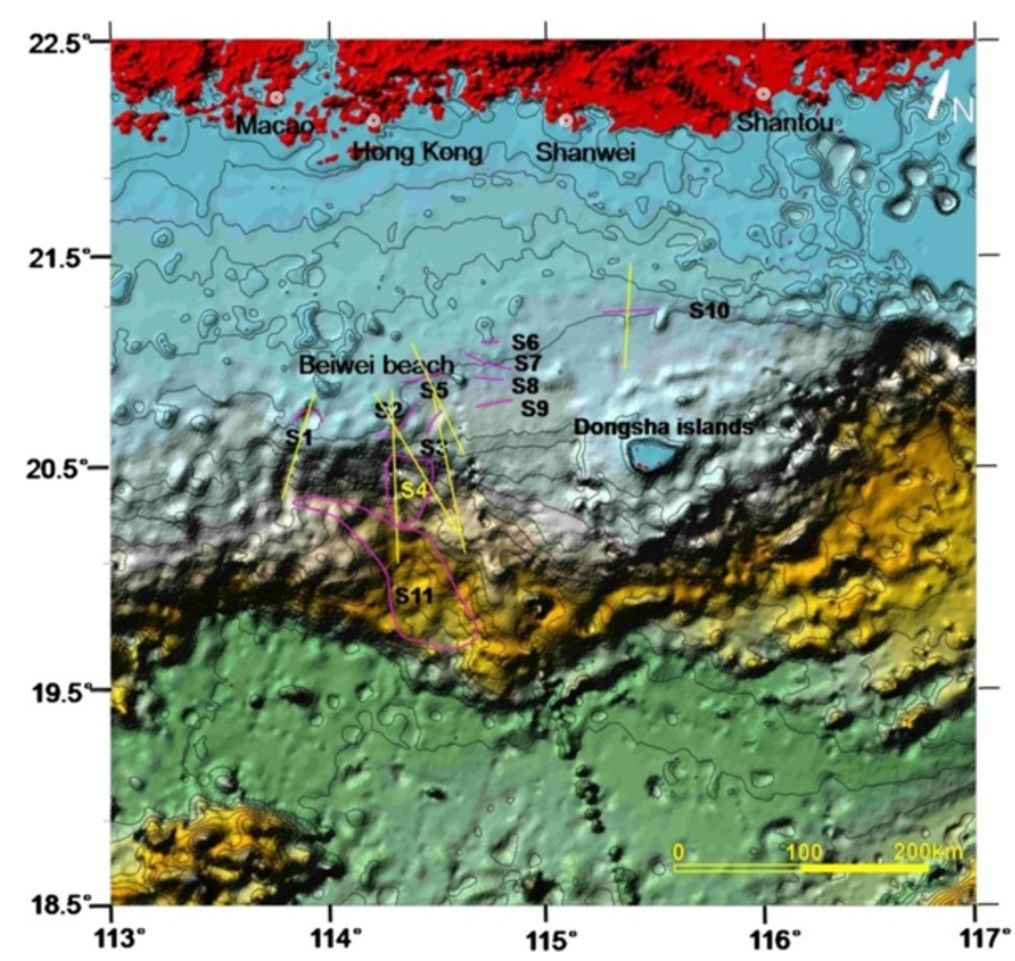

Figure 2 Distribution diagram of submarine landslides (After Fen et al., 1994 and Sun, 2011). S1-S11 are landslide codes; carmine lines refer to location or area of landslides; yellow lines refer to profile lines. 
Table 1 Description of submarine landslide belts (After Fen et al., 1994 and Sun, 2011)

\begin{tabular}{|c|c|c|c|c|c|c|c|}
\hline Code & $\begin{array}{c}\text { Depth } \\
(\mathrm{m})\end{array}$ & $\begin{array}{c}\text { Length } \\
(\mathrm{km})\end{array}$ & $\begin{array}{c}\text { Width } \\
(\mathrm{km})\end{array}$ & $\begin{array}{c}\text { Thickness } \\
\text { (m) }\end{array}$ & $\begin{array}{l}\text { Area } \\
\left(\mathrm{km}^{2}\right)\end{array}$ & $\begin{array}{l}\text { Volume } \\
\left(\times 10^{9} \mathrm{~m}^{3}\right)\end{array}$ & $\begin{array}{c}\text { Gradient } \\
\left({ }^{\circ}\right)\end{array}$ \\
\hline S1 & $190-250$ & 55 & 3 & $25-50$ & 110 & 4 & $2-4$ \\
\hline S2 & $210-230$ & 75 & 2 & $10-20$ & 150 & 2.2 & $2-3$ \\
\hline S3 & 420 & 55 & 5 & $10-20$ & 110 & 1.6 & $2-3$ \\
\hline S4 & $500-1800$ & 50 & 16 & $50-200$ & 400 & 50 & $3-4$ \\
\hline S5 & $150-200$ & 60 & 15 & $20-50$ & 105 & 3.7 & 1 \\
\hline $56-59$ & $150-370$ & $5-10$ & $3-4$ & $20-50$ & & & $1-9$ \\
\hline S10 & $150-250$ & 52 & $1-10$ & $10-20$ & 28 & 0.43 & 1 \\
\hline S11 & 2500 & 150 & 17.5 & 50 & 10000 & 500 & $1-3$ \\
\hline
\end{tabular}

landslide S4 and S11, other landslides are in SW zonal distribution along the outer bend line of the continental shelf, the ancient coastal line and the front scarp of the ancient delta. Specific locations, the water depth range and scales of these landslides are shown in Table 1. All these landslides are discovered by combining $2 \mathrm{D}$ and $3 \mathrm{D}$ seismic data and multi-beam waterdepth measurement (Marine Geological Survey Bureau of the Ministry of Geology and Mineral Resources, China 1993; Sun et al. 2008).

Features of submarine landslides can be clearly identified by using side sonar, depth measurement, sub-bottom profiling and single-channel seismograph. For example, features of back scarp (scarp, sharp slope or cliff), landslide valley or collapsed valley (depression or gully), landslide mass (hilly block), landslide bench and sliding surfaces can be known by using the foregoing geophysical prospecting methods. Figure 3 shows the landslide profiles of S1-S5 and S10, and schematizes some landslide features. Landslide S1 zone has prominent landslide scarp, collapsed valley and benches, with development of reverse benches, indicating that the landslide is at the preliminary stage and will continue the development. Landslides S2 and S3 have visible landslide back scarps, depressions, landslide benches and bedding flexure, indicating that Landslide S2 and S3 are active landslides, and will continue slide along the slopes. Landslide S5 has block collapses at the east and west ends, back scarp and layered landslide in the middle. Landslide S6 and S7 are layered landslides, with hilly deposits at the bottom of the slopes, featuring multiphase sliding. Landslide S8 and S9 have back scarps, with rocksoil collapse. Landslide S10 has imminent sliding cliff, collapsed valley, hilly landslide mass and arc-shaped sliding surface, featuring multiphase sliding. The largest depth of Landslide S4 is $200 \mathrm{~m}$, and the largest volume is $50 \times 10^{9} \mathrm{~m}^{3}$ (Table 1). Landslide S4 was developed from the outer bend of continental shelf, with development depth and slope obviously larger than Landslides S1-S3 and S5-S10 (Figure 2). Meanwhile, S4 has obvious movement of hilly blocks and multiple landslide benches; it is obviously active. Landslide S11 is a giant landslide, and is now formally named as Baiyun Landslide. Baiyun Landslide is in huge volume of $500 \times 10^{9} \mathrm{~m}^{3}$ and currently the largest landslide discovered in South China Sea. The multiphase activity of Baiyun Landslide and associations between its deformation and gas or fluid movement have been detected by using seismic wave, but the inducing mechanism of Baiyun Landslide is still under research (Li et al. 2014a, 2014b).

This paper focuses on prediction of tsunami disasters generated by submarine landslides, and thus will not give too much description of the submarine landslide characteristics. For detail features and stability of the submarine landslides in Baiyun Depression, please refer to relevant special documents (Fen et al. 1994; Sun et al. 2008; Sun 2011; Liu 2010).

\section{Modeling of potentially induced tsunamis}

Since initial investigation of submarine landslides by United States Geological Survey in early 1990s, studies

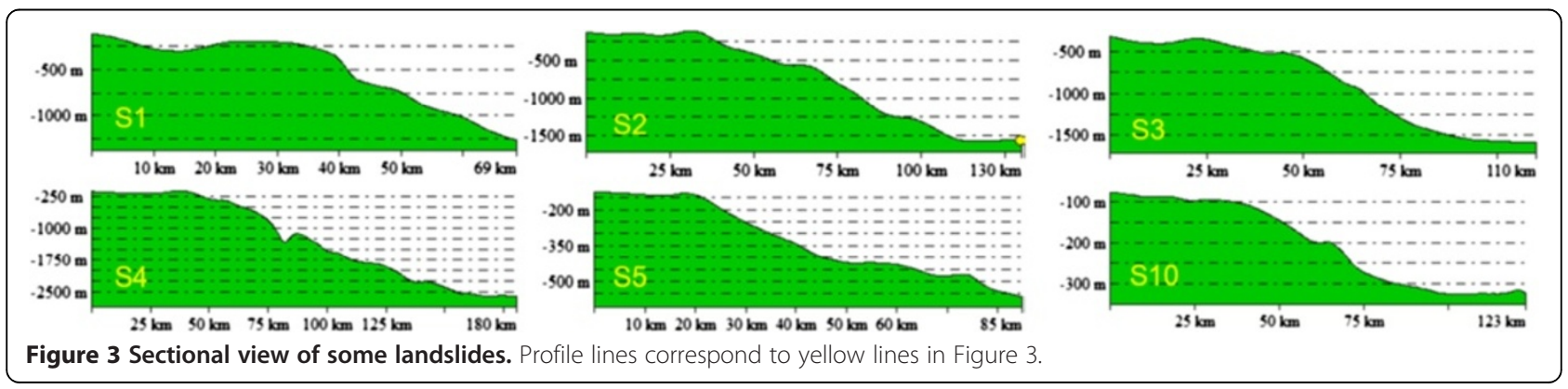


Table 2 Input/Output parameters of Landslide S4 in TOPICS

\begin{tabular}{lclc}
\hline Input parameters about S4 & & Output parameters about original tsunamis \\
\hline Barycenter initial depth & $1,350 \mathrm{~m}$ & initial acceleration & $0.18 \mathrm{~m} / \mathrm{s}^{2}$ \\
Mean incline angle & $3.5^{\circ}$ & Tsunami wavelength & $128,716.5 \mathrm{~m}$ \\
Initial length & $50,000 \mathrm{~m}$ & Max.Froude number & 1.74 \\
Initial maximum thickness & $62.5 \mathrm{~m}$ & trough amplitude & $-13.6 \mathrm{~m}$ \\
Initial maximum width & $16,000 \mathrm{~m}$ & peak amplitude & $3.67 \mathrm{~m}$ \\
Bulk density & $1,900 \mathrm{~kg} / \mathrm{m}^{3}$ & Tsunami source periods & $18.6 \mathrm{~min}$ \\
\hline
\end{tabular}

about submarine landslides and tsunami have been continuously deepened (Prior 1984; Ward 2001; Okal 2003; Ward and Day 2003; Masson et al. 2006; Uriten et al. 2009; Vanneste et al. 2011; Sue et al. 2011). In this paper, achievements of Grilli and Watts (2005), Enet et al. (2003) and Enet \& Grilli (2007) relating to submarine landslidegenerated tsunamis are used as reference. The rigid body sliding model established by Grilli and Watts (2005) is a symmetrical semi-elliptical sliding block, extending for a length of $\mathrm{B}$ along its long axis; the greatest thickness is $\mathrm{T}$; the sliding block moves on a slope with a gradient of $\theta$. Based on moment equilibrium plus gravity, hydraulic drag and buoyancy, they mathematically described the movement and initial surge field of the rigid body, formed a submarine landslide-generated surge source model and wrote it into the TOPICS module of Geowave. In this paper the submarine landslide-generated surge model in TOPICS is employed to predict the initial surge source generated by movement of Landslide S4, and Boussinesq equation FUNWAVE module of Geowave is utilized to
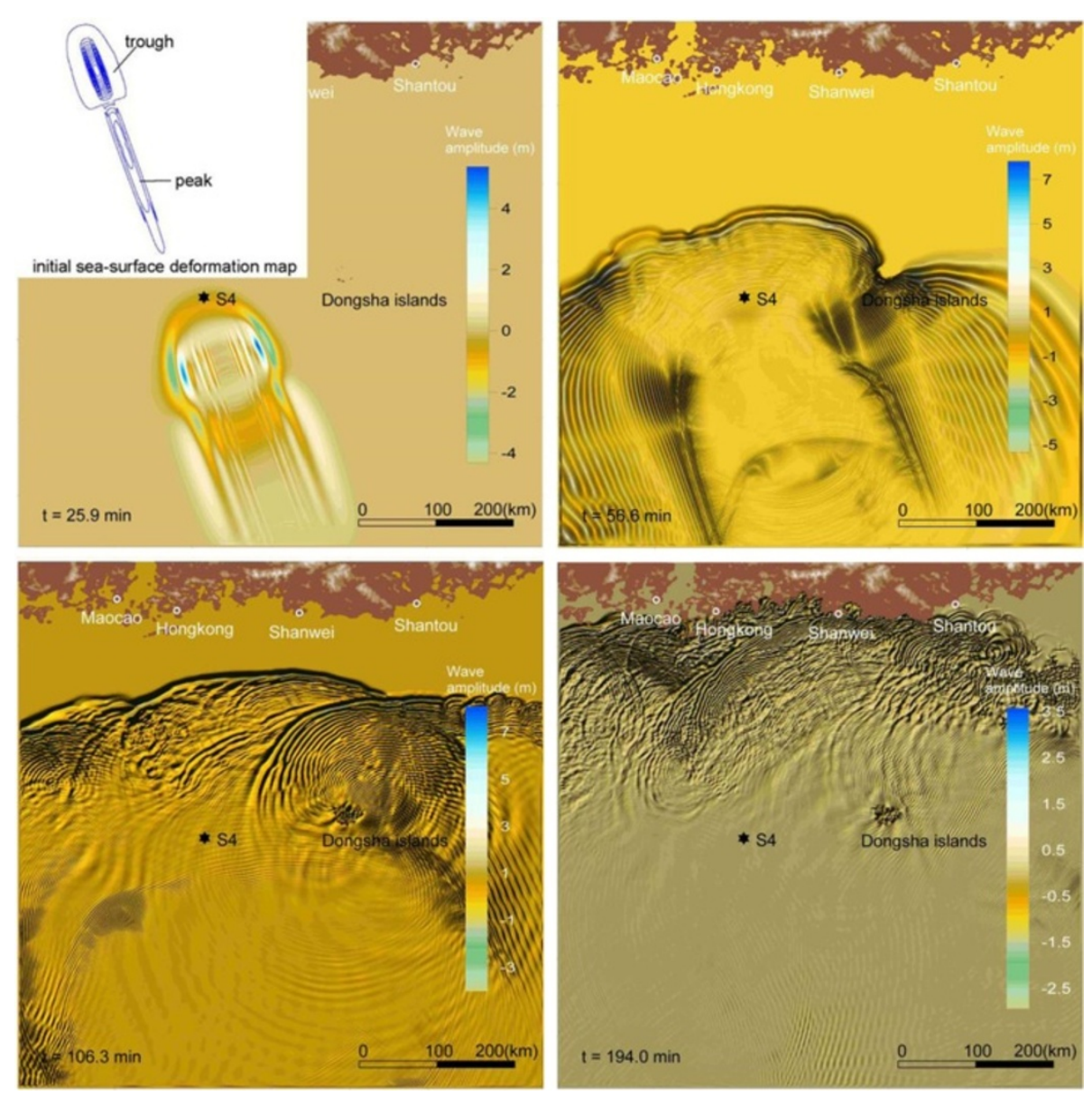

Figure 4 Instant sea amplitude diagram, indicating instant sea wave amplitudes at different time points to reflect conditions of a tsunami on the sea surface at corresponding time point. 
calculate spreading and run-up of surge waves (Applied Fluids Engineering Inc and University of Delaware, U.S.A 2008).

It is very expensive and unnecessary to evaluate the tsunami hazards for all submarine landslides in current situation; moreover, considering the research purposes of the paper, this research only selects a large and strongly active landslide for the prediction of tsunami hazards. Landslide S11 is the largest landslide in this area but has obvious multi-phase slide characteristics, with low possibility of inducing the entire slide only in a phase. However, due to unclear inducing mechanism, it is difficult to divide its sliding phases and potential sliding areas. Landslide S4 is selected for this prediction for the following reasons: 1) Landslide S4 has the second largest volume, and the biggest slope angle; 2) Landslide S4 is located within Baiyun Depression, featuring strong activity; 3) Landslide S4 lies in the region of NSCS which is a key target area for development of hydrocarbon in future, and depth exceeding $500 \mathrm{~m}$ is a condition for occurrence of natural gas and water mixture. Therefore, submarine Landslide S4 is taken as an example, and through calculation of tsunami generated by movement of Landslide S4, possible tsunami disasters in NSCS are assessed.

Based on the geological location of Landslide S4, a landsea computational domain (as shown in Figure 2) extending about $672 \mathrm{~km}$ long and $673 \mathrm{~km}$ wide was established, in which key coastal cities such as Macau, Hong Kong, Shantou and Shanwei cities in Guangdong Province were included, so were islands such as Dongsha Islands, islands at
Zhujiangkou and some islands near the continent. The bathymetric and topographic data is SRTM data from NASA. The submarine translation slide model of TOPICS is used to calculate initial tsunami source. For this translation slide model, the model is a tsunami source model established by Grilli and Watts et al. with advanced boundary element method based on full non-linear potential flow equations. This model is later extended and experimentally validated by Enet et al. (2003) and Enet \& Grilli (2007). The domain formed a 1,62 ×1,685 computational network comprising many discrete $400 \mathrm{~m} \times 400 \mathrm{~m}$ grid cells, with each time step of $0.58 \mathrm{~s}$ and totally 26,001 computing steps, about $16,000 \mathrm{~s}$ or $4.5 \mathrm{~h}$.

Table 2 shows the parameters of S4 input in TOPICS and relevant characteristic indicators of the output initial tsunami source.

Through calculation, conditions of tsunami generated by Landslide S4 were predicted. After sliding of Landslide S4, an initial surge field was formed with crest in the south and trough in the north (see output parameters in Table 2 \& Figure 4). Afterwards, the tsunami started spreading. It can be seen from the instant sea diagrams that the tsunami spread in all directions, but the strongest part was the tsunami waves vertical to the sliding direction of the landslide (Figure 4, $\mathrm{t}=25.9 \mathrm{~min}$ and $56.6 \mathrm{~min})$. Rows of water walls were formed and advanced towards the east/west direction firstly. During advancement towards the continent, waves arrived at Dongsha Island at about the 55th min; partial waves ran up to $15 \mathrm{~m}$. When passing by Dongsha Island, the

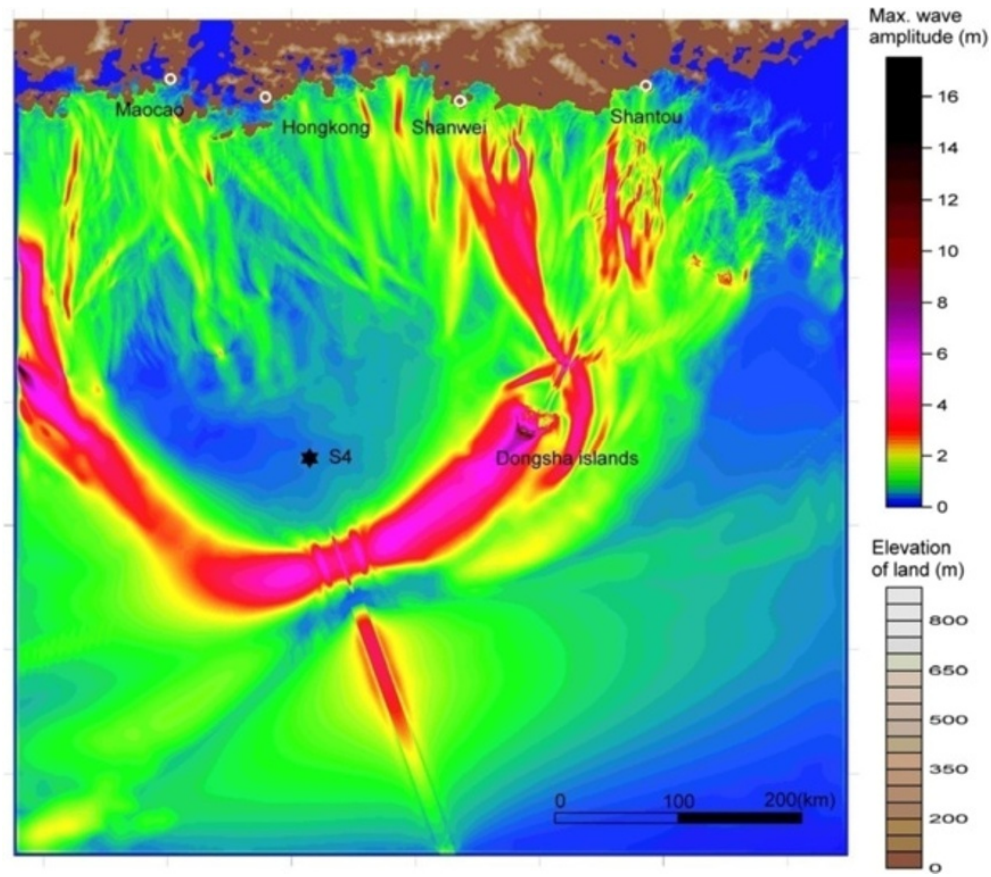

Figure 5 Maximum amplitudes of water particles in the computational domain within $4.5 \mathrm{~h}$. 


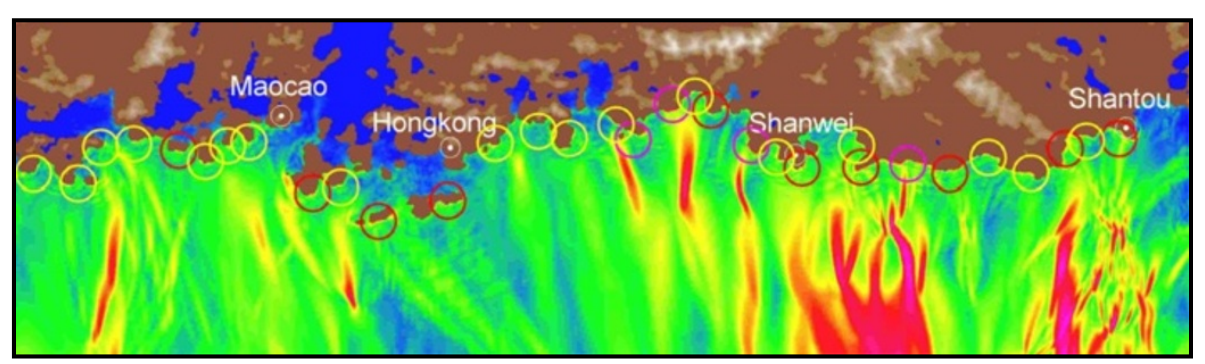

Figure 6 Coastal run-up diagram. Areas circled indicate abnormal run-ups compared with the surrounding areas. Yellow circles indicate run-ups of 1.5-2.5 m; red circles indicate run-ups of 2.5-3.5 m; carmine circles indicate run-ups of 3.5-5.5 m; other coastal run-ups are less than $1.5 \mathrm{~m}$.

tsunami flowed around and formed cross tsunami waves advancing towards the continent. This was common in other offshore areas (Figure 4, $\mathrm{t}=106.3 \mathrm{~min}$ ). When arriving at the coastal line, the first tsunami waves ran up, with reflection, refractions and diffractions, forming complex waveforms (Figure 4, $\mathrm{t}=194.0 \mathrm{~min}$ ).

The instant sea surface diagrams reflected conditions of the tsunami on the sea surface at different time points; the maximum amplitude diagram (Figure 5) reflected the maximum amplitudes of the calculation points in the computational domain within $4.5 \mathrm{~h}$. Though $4.5 \mathrm{~h}$ was long, as the wave velocity was positively correlated to the water depth, the tsunami waves could not reach all along the coastal line in $4.5 \mathrm{~h}$. In Figure 6, tsunami wavefronts waves reached the coastal line in areas except for the east area of Shantou. The maximum amplitude diagram clearly shows the general route of tsunami waves, particularly the spreading path of the tsunami waves after wave breaking offshore. The tsunami generated at the water depth of $1,350 \mathrm{~m}$ encountered reduction of water depth when spreading towards the continent, forming hydraulic jumps. Therefore, maximum amplitudes of $17.5 \mathrm{~m}$ in the computational domain occurred on Dongsha Islands, which is the first exposure of land in the propagating process. As the tsunami propagated for nearly $300 \mathrm{~km}$ long to reach the coast, great energy of the tsunami was consumed. At the water depth of about $100 \mathrm{~m}$, the maximum tsunami wave was about $6 \mathrm{~m}$; at the water depth of about $50 \mathrm{~m}$, the maximum tsunami wave was about $3 \mathrm{~m}$. Near the coastal line, the reduction of water depth leads to the shoaling effect of waves, getting higher and moving slower.

When arriving at the continent, the tsunami waves formed run-ups. The maximum run-up of $17.5 \mathrm{~m}$ caused by Landslide S4-generated tsunami occurred not in Figure 6 but on Dongsha Island in Figure 5. The maximum inundation lengths in the calculating area were about 1600 m located in Shanwei, $150 \mathrm{~m}$ in Hong Kong and $200 \mathrm{~m}$ in Shantou. In Figure 6, run-ups at the coastal line were shown amplified. There were four runup areas of 3.5-5.5 m, lying in the east and west sides of
Shangtou City. Two run-ups of $5.3 \mathrm{~m}$ occurred in Shanwei City and Yezhoushan of Haifeng County under Shanwei City. Additionally, there were ten run-ups of 2.5-3.5 m and eighteen run-ups of 1.5-2.5 $\mathrm{m}$ distributed crosswise along the coastal line (Figure 6). At other coastal lines in the computational domain, the tsunami ran up for about $1 \mathrm{~m}$.

The abnormal run-ups were significantly dependent to submarine canyons. It can be seen from Figure 7 that, seabed topography may impact nearshore surge height and costal run-ups. In nearshore area, the surge height in seabed ridge is higher than that in other places. While near the coast, the run-ups at both sides of submarine canyons are obviously higher those in other areas (Figure 7). All these indicate that submarine canyons near the coast can focus wave energy (Wijetunge 2009; Didenkulova and Pelinovsky 2010).

What did these run-ups mean to the coastal lines? Let's take Shanwei City as an example. In Shanwei City, there are seaside scenic spots, many factories, warehouses and docks, but no breakwaters; some waterside roads are no

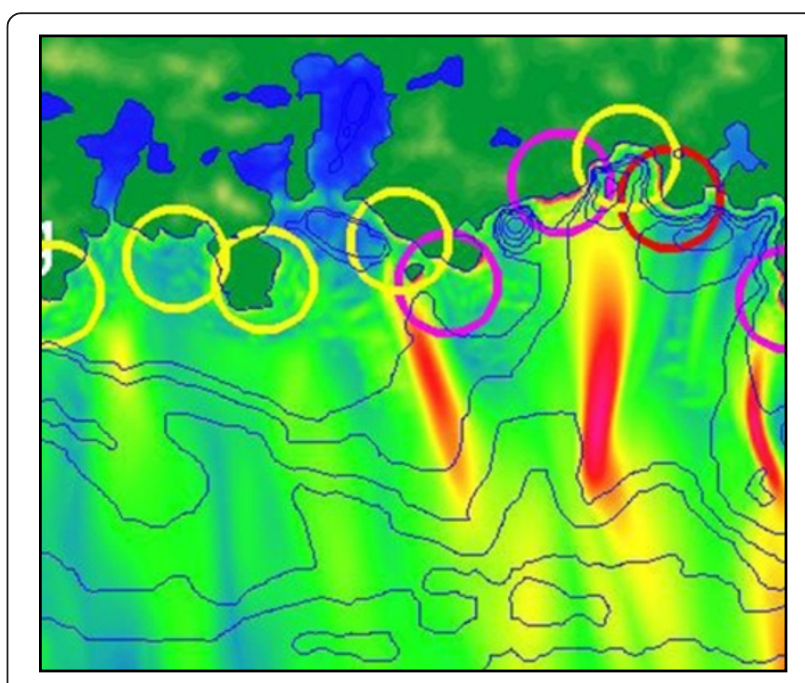

Figure 7 Enlarged map of part of Figure 6, located between Hong Kong and Shanwei. Blue lines were sounding lines. 


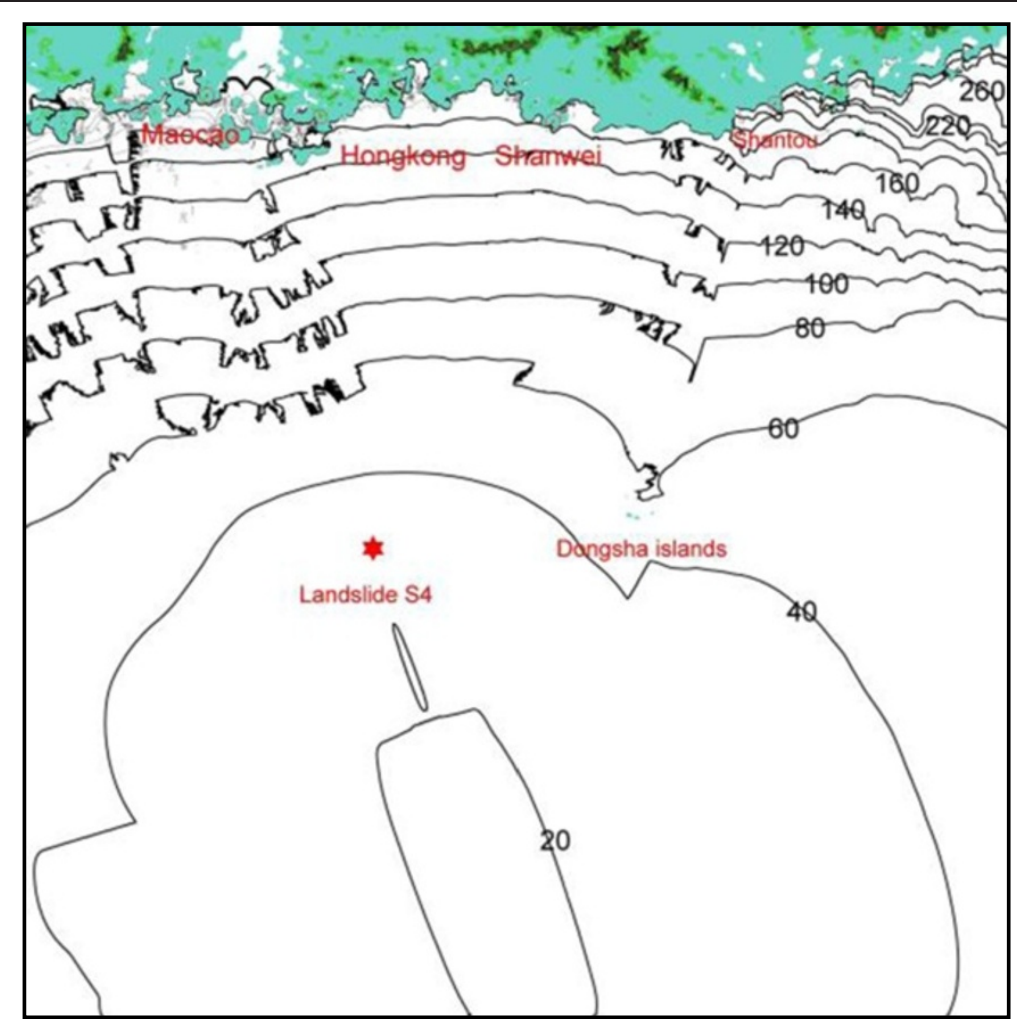

Figure 8 The tsunami travel time contour line map, the unit of contour lines are minute.

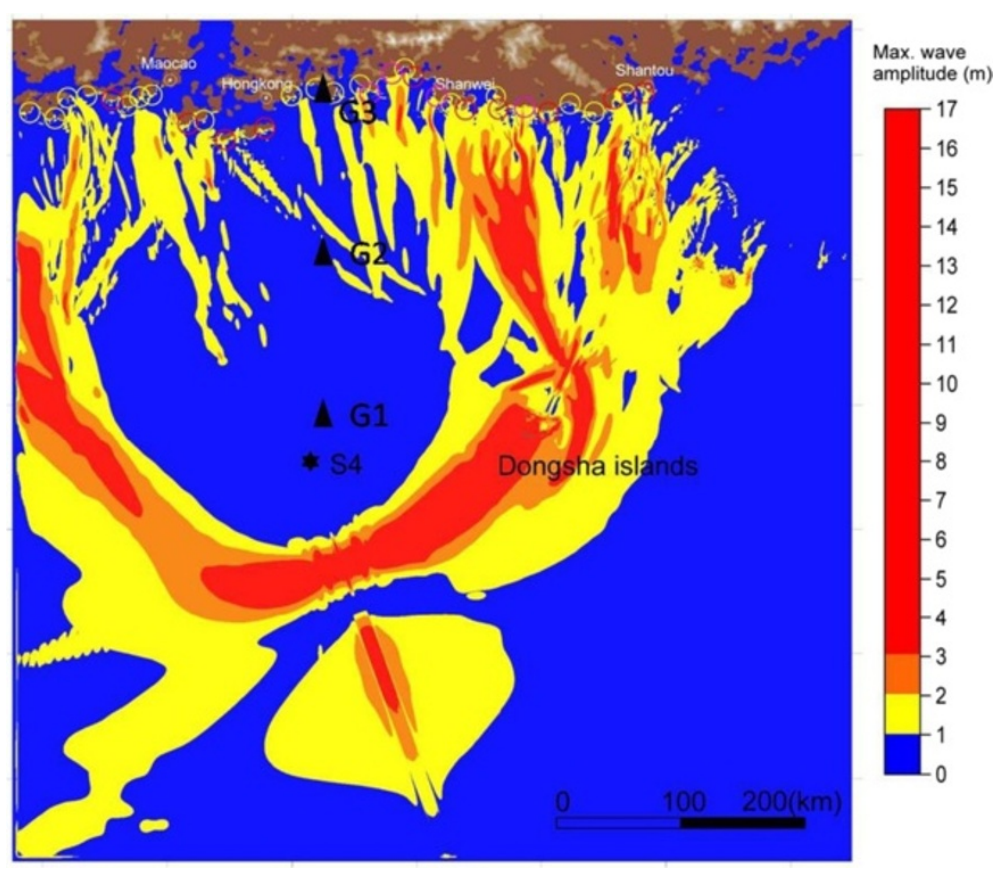

Figure 9 Warning division diagram: blue for area subject to blue warning area, yellow for area subject to yellow warning area, orange for area subject to orange warning area, red for area subject to red warning area. 


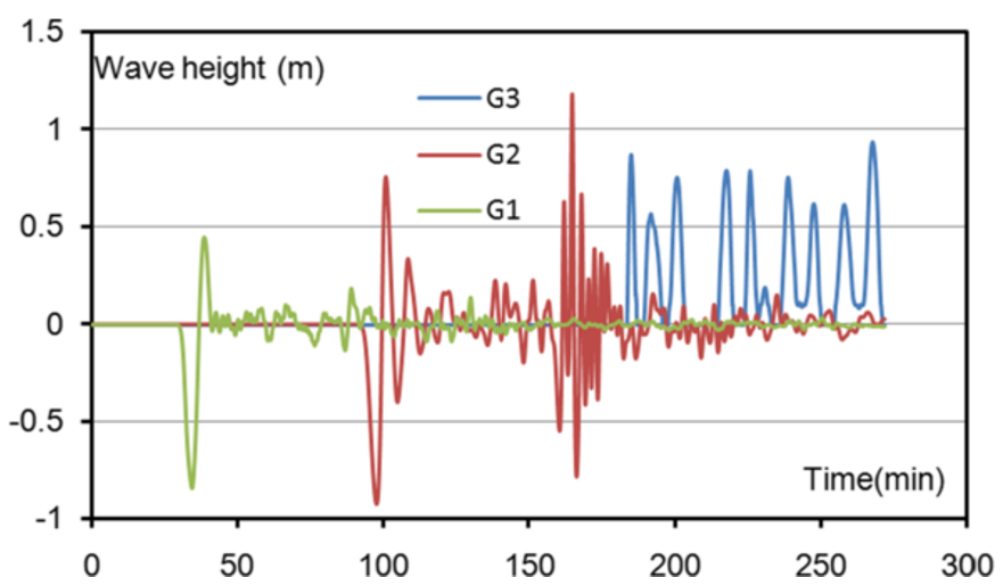

Figure 10 Hydrograph of typical points in the potential tsunami. The locations of G1 G3 can be seen in Figure 9 ., and G3 is on the coastal line of Dapeng Bay.

more than $5 \mathrm{~m}$ high. If some tsunami like tsunami induced to Landslide S4 occurs in NSCS, particularly in the 32 run-up splace mentioned above, the coastal production and living quarters will suffer greatly or even a catastrophe.

Also, the tsunami travel time (TTT) is one of most important information related to early-warning and evacuation plans. The phases of celerity are relative to the bathymetry (Le Méhauté 1976), so TTT map (Figure 8) is distributed like arch shape. As the coastal line is long, time for tsunami waves to arrive differs greatly. For example, after occurrence of the landslide, it took $75 \mathrm{~min}$ for tsunami waves to arrive at Dongsha Island, about $145 \mathrm{~min}$ to arrive at off-island of Hong Kong, about $160 \mathrm{~min}$ to arrive at Shangwei City, $200 \mathrm{~min}$ to arrive at Shantou City and $240 \mathrm{~min}$ to arrive at Macau. If wave buoys are set at depth of $200 \mathrm{~m}$, early-warning will be emitted when tsunami passing the buoy, thus valuable time of 1 hour will be left for the evacuation.

According to the Contingency Plan against Disasters of Storm Surges, Sea Waves, Tsunamis and Sea Ice (State Oceanic Administration of China 2009), the Landslide S4-generated tsunamis in the computational domain can be rated for warning (Figure 9). According to this Contingency Plan, the tsunami influence region can be rated as follows: blue warning area for $0-1 \mathrm{~m}$, yellow warning area for 1-2 $\mathrm{m}$, orange warning area for 2-3 $\mathrm{m}$ and red warning area for above $3 \mathrm{~m}$. Distribution of the warning areas is shown in Figure 8. As the computational domain is limited, a Landslide S4-generated tsunami has impact on more than the computational domain, and thus the warning area is wider than that covered in prediction.

Meanwhile, in a warning and emergency response plan, it shall be considered that there might be more than one wave crest attacks due to flow disturbance by islands. From the three typical hydrographs shown in Figure 10, it can be known that there were two violent attacks at offshore of Hong Kong (the second attack higher than the first attack). The coastal line of Dapeng Bay suffered multiple waves' attacks that lasted for more than 1.5 hours with wave height of about $0.8 \mathrm{~m}$. Multiple attacks and long duration of a tsunami shall be emphasized in emergency response and warning.

This tsunamis hazard assessment can be compared with 1953 Suva tsunami of Fiji, some underwater landslidegenerated tsunamis in the Padang region, Indonesia, and the Grand Bank tsunami of North American coastline. Based on Rahiman et al.'s (2007) analysis, a simulation using a 60 million cubic metre submarine landslide located at the head of the Suva Canyon, $4 \mathrm{~km}$ to the

Table 3 The relatived data of submarine landslides and its tsunamis

\begin{tabular}{|c|c|c|c|c|c|}
\hline Name & Water depth & Landslide volume & Initial wave peak & Initial wave trough & Max. run-up \\
\hline S4 landslide & $1350 \mathrm{~m}$ & $50 \times 10^{9} \mathrm{~m}^{3}$ & $3.67 \mathrm{~m}$ & $-13.6 m$ & $5.5 \mathrm{~m}$ \\
\hline Suva landslide & $125 \mathrm{~m}$ & $0.05 \times 10^{9} \mathrm{~m}^{3}$ & $11 \mathrm{~m}$ & $-40.8 \mathrm{~m}$ & $10 \mathrm{~m}$ \\
\hline Grand Bank & $10,000 \mathrm{~m}$ & $200 \times 10^{9} \mathrm{~m}^{3}$ & (Max.) 3-8 m & & $13 \mathrm{~m}$ \\
\hline \multirow[t]{3}{*}{ Pandang landslides } & $1300 \mathrm{~m}$ & $0.7 \times 10^{9} \mathrm{~m}^{3}$ & 2.0 & - & $3.6 \mathrm{~m}$ \\
\hline & $1300 \mathrm{~m}$ & $0.5 \times 10^{9} \mathrm{~m}^{3}$ & 2.1 & - & $3.6 \mathrm{~m}$ \\
\hline & $1300 \mathrm{~m}$ & $0.1 \times 10^{9} \mathrm{~m}^{3}$ & 0.2 & - & - \\
\hline
\end{tabular}


WSW of Suva City reproduces the observed run-up. Based on Sascha et al.'s (2010) study, some landslides $70 \mathrm{~km}$ off Padang (Western Sumatra, Indonesia) may generate tsunamis, and the yielding maximum run-up is about $3 \mathrm{~m}$, while Padang with over 750,000 inhabitants exhibits high tsunami vulnerability due to its very low elevation. On November 18th, 1929, in North American coastline, a submarine landslide occurred near the Grand Banks by a large earthquake with $\mathrm{Mw}=7.2 \mathrm{mo-}$ ment magnitude causing 28 fatalities (Fine et al. 2005).

Some main relatived analysis data of The S4 landslide, Suva landslide, Pandang landslides and its tsunamis are listed in Table 3. The comparison shows that the results of tsunami generated by $\mathrm{S} 4$ landslide are in the middle of the examples. Some landslide with smaller volume has bigger tsunami than S4. Tsunami generated by much bigger landslide is not such bigger than the tsunami generated by S4 landslide. The critical parameters for tsunami generation are the landslide volume and water depth.

\section{Findings}

Northern South China Sea, hot spot for oil and gas research and production, is a critical area for China. Some significant submarine landslides are briefly described. Tsunamis modelling are tested for some landslides sources in order to point out areas at risk. The formation, spreading and run-up of tsunamis generated by Landslide S4 within $4.5 \mathrm{~h}$ in a sea area of $672 \times 673 \mathrm{~km}^{2}$ are predicted by using the GEO-WAVE Boussinesq model. As calculated, the greatest height of tsunami generated by Landslide S4 is $17.5 \mathrm{~m}$, and the greatest runup formed on the coastal line is $5.3 \mathrm{~m}$. This shows that numerous places of high vulnerability along seashore are potentially prone to significant tsunami disasters.

\section{Conclusions}

Based on distribution of submarine landslides near Baiyun Depression of NSCS and prediction of tsunamis generated by submarine Landslide S4, the following conclusions are drawn with suggestions proposed:

1) The NSCS has mature development of hydrocarbon; Baiyun Depression in this area has developed eleven landslides of different scales. Movement of landslides in this area may cause profound impact and damages.

2) Suppose submarine Landslide S4 occurs. The TOPICS submarine landslide-generated surge model is used to establish a $672 \times 673 \mathrm{~km}^{2}$ submarine landslide-generated tsunami model, so as to predict formation, spreading and run-ups within $4.5 \mathrm{~h}$ of a tsunami.

3) Landslide $\$ 4$ may generate a tsunami with the maximum height of $17.5 \mathrm{~m}$ (occurring on Dongsha
Islands). General wave height of tsunami attacks at the coastal line is less than $1.5 \mathrm{~m}$, with 32 abnormal high run-ups. The maximum run-up at the continental coastal line is $5.3 \mathrm{~m}$ and the maximum inundation is $1600 \mathrm{~m}$, occurring at Shanwei City.

4) Tsunami warning areas are divided according to the tsunami contingency plan of China. As tsunami propagation correlates with water depth, time for the tsunami to reach different points differs greatly, providing a time difference for warning; for warning and contingency, multiple wave attacks and long wave duration shall be considered.

Prediction of Landslide S4-generated tsunamis suggests that local tsunami hazard might occur in China. However, as rare studies have been done on local submarine landslide-generated tsunamis in China, the government and researchers lack of estimations about damages brought by a submarine landslide-generated tsunami. Therefore, more efforts shall be made to investigate potential damages caused by a submarine landslide, particularly the submarine landslides at Baiyun Depression in NSCS. Additionally, submarine landslide-generated tsunamis shall be made widely known, so as to avoid damages technically and socially.

Competing interests

The authors declare that they have no competing interests.

\section{Authors' contributions}

SY and HB choosed the research direction of tsunami generated by submarine landslide, collected informations of submarine landslides around Baiyun depression, NSCS, carried out the numerical simulation study on tsunami generated by landslide, and drafted the manuscript. Both authors read and approved the final manuscript.

\section{Acknowledgements}

This study has been funded by the National Marine Public Scientific Research (ID: 201005005) and National Natural Science Foundation of China (project ID: 41372321). We would like to extend our thanks to Dr. Hu Guanghai and Senior Engineer Song Yupeng from the First Institute of Oceanography, SOA for their provision of large quantities of useful data and information. Finally, the authors want to thank two anonymous reviewers, Prof. Wang Fawu, Dr. Yang Hufeng and Prof. Patrick Wassmer for their helpful suggestion. This MS evaluates the potentiality for submarine landslides to induce tsunamis in Northern South China Sea. Northern South China Sea, hot spot for oil and gas research and production, is a critical area for China. Some significant submarine landslides are briefly described and the authors investigate the potential for landslide-induced tsunamis. The local governments along the shoreline and offshore economics are not aware of the threat to this area related to large submarine landslides and associate tsunamis. Tsunamis modelling are tested for some landslides sources in order to point out areas at risk. This approach shows that numerous places of high vulnerability along seashore are potentially prone to significant tsunami disasters. This research, focused on potential threat linked to local tsunami sources, is in its early stage in China but it is of capital importance for the local people, local government and offshore economics. This MS also reminds many researchers and research institutions that one should not ignore local sources for tsunami generation in China.

\section{Author details}

${ }^{1}$ The First Institute of Oceanography, SOA. Xianxialing Road 6\#, Laoshan District, Qingdao City, China. ${ }^{2}$ Wuhan Center of China Geological Survey, Guanggu Road 69\#, Wuhan City, China. 
Received: 14 August 2014 Accepted: 20 October 2014

Published online: 18 December 2014

\section{References}

Applied Fluids Engineering Inc, University of Delaware, U.S.A (2008) Geowave 1.1 Tutorial

Chen Y, Chen Q, Zhang W (2007) Tsunami disaster in China. Journal of Natural Disasters 16(2):1-6

Didenkulova I, Pelinovsky E (2010) Runup of tsunami waves in U-shaped bays. Pure Appl Geophys 168:1239-1249

Enet F, Grilli ST and Watts P (2003) Laboratory Experiments for Tsunamis Generated by Underwater Landslides: Comparison with Numerical Modeling. Proceeding of the $13^{\text {th }}$ International Offshore and Polar Engineering Conference: 372-379

Enet F, Grilli ST (2007) Experimental study of tsunami generation by three-dimensional rigid underwater landslides. J Waterw Port Coastal Ocean Eng 133:442-454

Fang C, Zhang W (2010) Mechanism and analysis of landslide on the seabed due to the decomposition of gas hydrate. Chinese Journal of Studia Marina Sinica 50:149-156

Fen W, Shi Y, Chen L (1994) Research for seafloor landslide stability on the outer continental shelf and the upper continental slope in the northern south China Sea. Mar Geol Quat Geol 14(2):81-94

Fine IV, Rabinovich AB, Bornhold BD, Thomson RE, Kulikov EA (2005) The Grand Banks landslide-generated tsunami of November 18, 1929: prelaminary analysis and numerical modeling. Mar Geol 215:45-57

Fuchs H, Heller V, Hager WH (2010) Impulse wave run-over: experimental benchmark study for numerical modeling. Exp Fluids 49:985-1004

Gong Z, Li S (1997) Preliminary Analysis of Basins and Petroleum Accumulation in the Northern Continental Margin Basin of South China Sea. Chinese Science Press, Beijing

Grilli ST, Watts P (2005) Tsunami generation by submarine mass failure. Part I: modeling, experimental validation, and sensitivity analysis. J Water Port Coastal Ocean Eng 131:283-297

Hu T, Ye Y (2006) Prediction models of landslide tsunami and its application. Chinese Journal of Marine Sciences 24(3):21-30

ITDB/WLD (2007) Integrated Tsunami Database for the World Ocean, Version 6.51 of February 20, 2007. CD-ROM, Tsunami Laboratory, ICMMG SD RAS, Novosibirsk

Jiang X (2009) Forming conditions and genetic analysis of natural gas hydrate. Coal Geology of China 21(12):07-11

Le Méhauté B (1976) An Introduction to Hydrodynamics and Water Waves. Springer, New York

Levin B, Nosov M (2009) Physics of Tsunamis. Springer, Netherlands 1-29

Li W, Wu S, Wang X, Zhao F, Wang D, Mi L, Li Q (2014a) Baiyun slide and its relation to fluid migration in the northern slope of Southern China Sea. Submarine Mass Movements and Their Consequences 37:105-115

Liu F (2012) A Safety evaluation for Submarine Slope Instability of the Northern South China Sea Due to Gas Hydrate Dissociation, The thesis for Ph.D. Institute of Oceanology, Chinese Academy of Sciences, Qingdao

Locat J, Lee HJ (2002) Submarine landslide: advances and challenges. Canada Geotechnology Journal 39(1):193-212

Marine Geological Survey Bureau of the Ministry of Geology and Mineral Resources, China (1993) Marine Engineering Geology Report of Zhunjiangkou Basin. South China Sea

Masson DG, Harbitz CB, Wynn RB, Pedersen G, LØvholt F (2006) Submarine landslides: processes, triggers and hazard prediction. Phil Trans A Math Phys Eng Sci 364:2009-2039

MiL ZG, Shen H (2008) Eocene-lower oligocene sedimentation characteristics of Baiyun sag in the deep water area of Pearl River mouth basin. Acta PetroleiSinica 29(1):29-33

Li W, Shiguo W, Wang X, Zhao F, Wang D, LijunMi QL (2014b) Baiyun Slide and its relation to fluid migration in the Northen slope of Southern China Sea. Adances in Natural and Technological Hazard Research 37:105-113

Norwegian Geotechnical Institute (NGI) (2005) Offshore geohazards[R]. Summary report for research institution-based strategic project 2002-2005, NGI report No.20021023-2

Okal EA (2003) T waves from the 1998 Papua New Guinea earthquake and its aftershocks: timing the tsunamigenic slump. Pure Appl Geophys 160:1843-1863
Prior DB (1984) Subaqueous landslides. Proceedings of the IV International Symposium on Landslides, Toronto 1:179-196

Rahiman IHT, Pettinga JR, Watts P (2007) The source mechanism and numerical modeling of the 1953 Suva tsunami, Fiji. Mar Geol 237:55-70

Sascha B, Andrey YB, Christoph G, Stefan L (2010) Hazard assessment of underwater landslide-generated tsunamis: a case study in the Padang region, Indonesia. Nat Hazards 53:205-218

Shi W, Chen H, Chen C (2006) Modeling of pressure evolution and hydrocarbon migration in the Baiyun Depression, Pearl River mouth basin, China. Earth Science-Journal of China University of Geosciences 31(2):229-336

State Oceanic Administration of China (2009) Contingency Plan against Disasters of Storm Surges, Sea Waves, Tsunamis and Sea Ice, NO.685

Sue LP, Nokes RI, Davidson MJ (2011) Tsunami generation by submarine landslides: comparison of physical and numerical models. Environ Fluid Mech 11:133-165

Sun Y (2011) The Mechanism and Prediction of Deepwater Geohazard in the Northern of South China Sea, The thesis for Ph.D. Institute of Oceanology, Chinese Academy of Sciences, Qingdao

Sun Y, Wu S, Wang Z, Li Q, Wang X, Dong D, Liu F (2008) The geometry and deformation characteristics of Baiyun submarine landslide. Mar Geol Quat Geol 6:69-77

Sun Z, Pang X, Zhong Z (2005) Dynamics of tertiary tectonic evolution of the Baiyun Sag in the Pearl River mouth basin. Chinese Journal of Earth Science Frontiers 12(4):489-498

Tinti S, Bortolucci E (2000) Energy of water waves induced by submarine landslides. Pure Appl Geophys 157:281-318

Tinti S, Bortolucci E, Armigliato A (1999) Numerical simulation of the landslide-induced tsunami of 1988 on Vulcano Island, Italy. Bull Volcanol 61:121-137

Uriten B, Twichell D, Lynett P, Geist E, Chaytor J, Lee H, Buczkowski B, Flores C (2009) Regional Assessment of Tsunami Potential in the Gulf of Mexico Report to the National Tsunami Hazard Mitigation Program. Geological Survey, U.S

Vanneste M, Forsberg CF, Glimsdal S, Harbitz CB, Issler D, Kvalstad TJ, Løvholt F, Nadim F (2011) Submarine Landslides and their Consequences: What do we know, what can we do? Proceedings of the second World Landslide Forum, Rome

Ward SN (2001) Landslide tsunami. J Geophys Res 106(6):11201-11215

Ward SN, Day S (2003) Ritter Island Volcano-lateral collapse and the tsunami of 1888. Geophys J Int 154:891-9-2

Wijetunge JJ (2009) Field measurements and numerical simulations of the 2004 tsunami impact on the east coast of Sri Lanka. Pure Appl Geophys 16:593-622

Yang W, Zhang Y, Li B (2011) Types and characteristics of deepwater geologic hazard in Qiongdongnan of the South China Sea. Offshore Oil $31(1): 1-7$

Zhu W, Zhang G, Yang S (2007) Gas Geology in the Northern Continental Margin Basin of South China Sea. Chinese Petroleum Industry Press, Beijing

\section{doi:10.1186/s40677-014-0007-0}

Cite this article as: Yongfu and Bolin: A Potential Tsunami impact assessment of submarine landslide at Baiyun Depression in Northern South China Sea. Geoenvironmental Disasters 2014 1:7.

\section{Submit your manuscript to a SpringerOpen ${ }^{\circ}$ journal and benefit from:}

- Convenient online submission

Rigorous peer review

- Immediate publication on acceptance

- Open access: articles freely available online

- High visibility within the field

- Retaining the copyright to your article

Submit your next manuscript at $>$ springeropen.com 